PREPARED FOR THE U.S. DEPARTMENT OF ENERGY, UNDER CONTRACT DE-AC02-76CH03073

PPPL-3670

PPPL-3670

UC-70

Neutral Beam Injection Requirements and Design Issues for the National Compact Stellarator Experiment

by

H.W. Kugel, H. Neilson, W. Reiersen, M. Zarnstorff, and M. Cole

February 2002

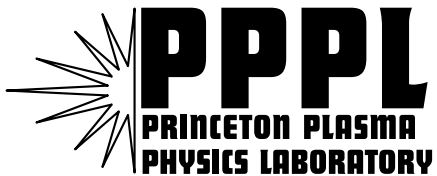

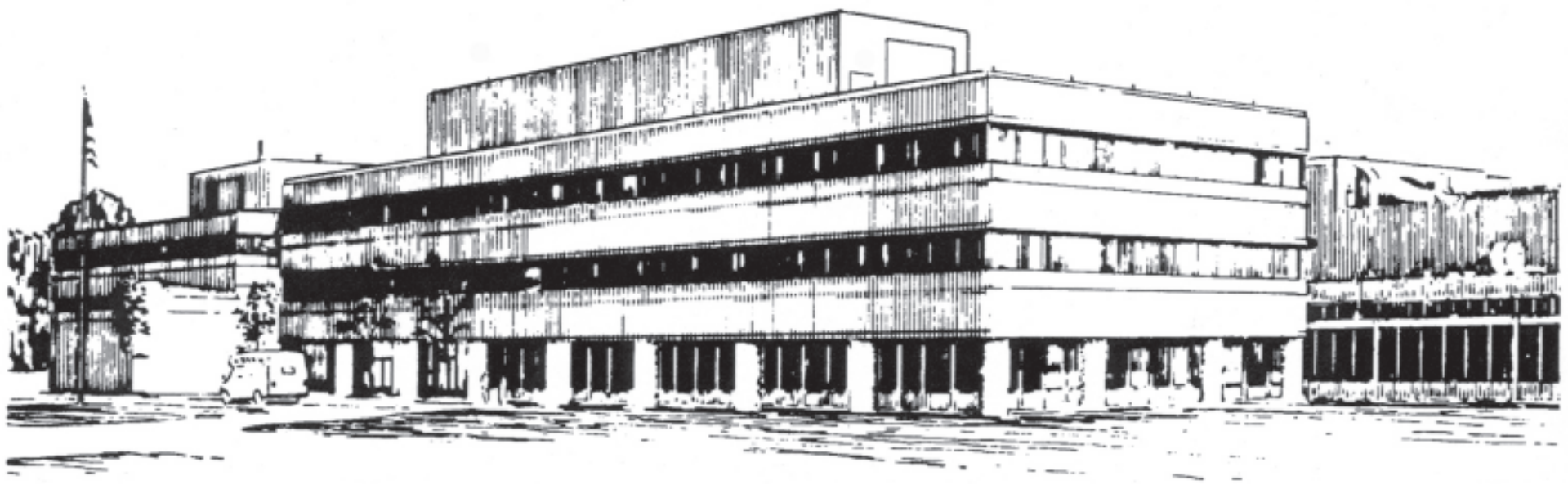

PRINCETON PLASMA PHYSICS LABORATORY PRINCETON UNIVERSITY, PRINCETON, NEW JERSEY 


\section{PPPL Reports Disclaimer}

This report was prepared as an account of work sponsored by an agency of the United States Government. Neither the United States Government nor any agency thereof, nor any of their employees, makes any warranty, express or implied, or assumes any legal liability or responsibility for the accuracy, completeness, or usefulness of any information, apparatus, product, or process disclosed, or represents that its use would not infringe privately owned rights. Reference herein to any specific commercial product, process, or service by trade name, trademark, manufacturer, or otherwise, does not necessarily constitute or imply its endorsement, recommendation, or favoring by the United States Government or any agency thereof. The views and opinions of authors expressed herein do not necessarily state or reflect those of the United States Government or any agency thereof.

\section{Availability}

This report is posted on the U.S. Department of Energy's Princeton Plasma Physics Laboratory Publications and Reports web site in Fiscal Year 2002. The home page for PPPL Reports and Publications is: http://www.pppl.gov/pub_report/

DOE and DOE Contractors can obtain copies of this report from:

U.S. Department of Energy

Office of Scientific and Technical Information

DOE Technical Information Services (DTIS)

P.O. Box 62

Oak Ridge, TN 37831

Telephone: (865) 576-8401

Fax: (865) 576-5728

Email: reports@adonis.osti.gov

This report is available to the general public from:

National Technical Information Service

U.S. Department of Commerce

5285 Port Royal Road

Springfield, VA 22161

Telephone: 1-800-553-6847 or

(703) 605-6000

Fax: (703) 321-8547

Internet: http://www.ntis.gov/ordering.htm 


\title{
Neutral Beam Injection Requirements And Design Issues For The National Compact Stellarator Experiment*
}

\author{
H. W. Kugel, H. Neilson, W Reiersen, and M. Zarnstorff \\ Princeton Plasma Physics Laboratory, Princeton, NJ 08543, USA \\ M. Cole, Oak Ridge National Laboratory, Oak Ridge TN, 37831, USA
}

\begin{abstract}
NCSX will require $6 \mathrm{MW}$ of 50 keV Neutral Beam Injection with initial pulse lengths of 500 msec and upgradeable to pulse lengths of $1.5 \mathrm{sec}$. This paper discusses the NCSX NBI requirements and design issues, and shows how these are provided by the candidate PBX-M NBI system.
\end{abstract}

\section{INTRODUCTION}

The National Compact Stellarator Experiment (NCSX) will be the primary research tool for understanding the physics of compact stellarators. NCSX will investigate the effects of 3-dimensional plasma shaping, of internally- and externallygenerated sources of rotational transform, and of quasi-axisymmetry on the stability and confinement of toroidal plasmas. Auxiliary heating is required to achieve the high temperature, high-beta plasma conditions needed to accomplish the NCSX research goals. A total of $12 \mathrm{MW}$ can be accommodated by the device design, $6 \mathrm{MW}$ of tangential Neutral Beam Injection (NBI) and $6 \mathrm{MW}$ of RF heating. This paper discusses the NCSX NBI requirements and design issues, and shows how these are provided by the candidate PBX-M NBI system.

\section{NEUTRAL BEAM SYSTEM CHARACTERISTICS}

\section{A. Available Injection Power}

NCSX will use the present PBX-M NBI system, consisting of 4 beamlines. This NBI system was used previously for PDX, PBX, PBX-M. The ion sources have $30 \mathrm{~cm}$ circular copper grids and a focal length of $440 \mathrm{~cm}$. Each ion source was fabricated, and fully qualified in 1979-1980 on the ORNL NB Test Stand to power levels of 1.5 MW, $\mathrm{H}^{0}$ (@ $\left.50 \mathrm{KV}, 100 \mathrm{~A}, 0.3 \mathrm{sec}\right)$ for the PDX experimental program[1]. In addition at ORNL, one ion source was demonstrated to yield $2 \mathrm{MW}, \mathrm{D}^{0}$ (@) $50 \mathrm{KV}, 70 \mathrm{~A}, 0.3 \mathrm{sec})$. As expected, the injected power for a given species was found proportional to the injection energy to the $5 / 2$ power. Subsequent testing after installation on PDX demonstrated the capability to inject with four sources up to $8.3 \mathrm{MW}$ $\mathrm{D}^{0}$ in the absence of magnetic fields. In the PDX machine enviroment, the presence of stray magnetic fields and finite transition duct pressure $\left(\sim 10^{-4}\right.$ torr $)$ reduced the available power to $6.5-7.0 \mathrm{MW} \mathrm{D}^{0}$. This loss of reionization power of $12-18 \%$ will be regained in NCSX by reinstalling the $100 \mathrm{kl} / \mathrm{s}$ cryopumping capability of the original design. Table 1 shows the NBI system injected power capability and the effects of fringe fields.

TABLE 1

NBI POWER CAPABILITY AND REIONIZATION LOSSES

\begin{tabular}{|c|c|}
\hline & 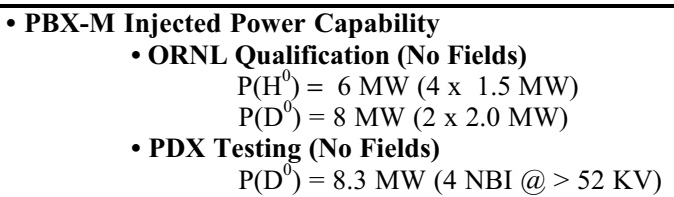 \\
\hline & 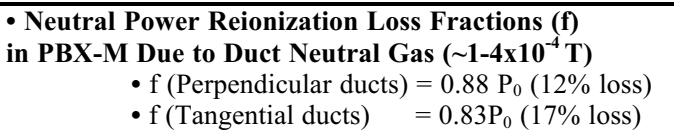 \\
\hline
\end{tabular}

\section{B. Neutral Species Ratios}

Typical species measurements performed at ORNL with equilibrium density neutralizer cells using ion dump yields found ion source species ratios of $\mathrm{H}^{0}(\mathrm{E}): \mathrm{H}^{0}(\mathrm{E} / 2): \mathrm{H}^{0}(\mathrm{E} / 3)=63: 20: 17$, and neutral beam power output ratios of $\mathrm{P}^{0}(\mathrm{E}): \mathrm{P}^{0}(\mathrm{E} / 2): \mathrm{P}^{0}(\mathrm{E} / 3)=80: 13: 7$. On PDX, with $\mathrm{D}^{0}$ at $47 \mathrm{keV},(1.6 \mathrm{MW})$, Rutherford Backscatter Spectroscopy [2] on the injected neutrals found neutral particle ratios of $\mathrm{D}^{0}(\mathrm{E}): \mathrm{D}^{0}(\mathrm{E} / 2): \mathrm{D}^{0}(\mathrm{E} / 3)=$ $53: 32: 15$, and neutral power ratios of $\mathrm{P}^{0}(\mathrm{E}): \mathrm{P}^{0}(\mathrm{E} / 2): \mathrm{P}^{0}(\mathrm{E} / 3)=72: 21: 7$.

\section{Neutral Power Pulse Length}

The neutral beamline power handling surfaces are engineered to operate at a maximum of $500 \mathrm{msec}$ pulse lengths at the peak power density of $3 \mathrm{~kW} / \mathrm{cm}^{2}$. In addition to power conditioning each of the ion sources to pulse lengths of $300 \mathrm{msec}$ in 19791980, ORNL demonstrated one ion source to operate at $500 \mathrm{msec}$ pulse lengths using $\mathrm{H}^{0}$ at about $50 \mathrm{KV}$, 90A [1]. Similar results were obtained on PBX-M, where each of the 4 neutral beamlines was demonstrated to operate with $\mathrm{D}^{0}$ at $\sim 40 \mathrm{KV}, 1 \mathrm{MW}$, 
to pulse lengths of 500 msec. PBX-M initiated preparations for operation to higher powers at 500 msec for both $\mathrm{H}^{0}$ and $\mathrm{D}^{0}$, and this capability should be considered available for NCSX. In addition, the MAST experiment at Culham Science Center, UK, which is presently using similar ORNL style beamlines is planning to upgrade to $1.5-3$ pulse length capability. This effort may provide a useful long pulse technology demonstration for NCSX NBI.

\section{Ion Source Focal Length, Focusing, and Power Density Profiles}

A PBX-M ion source has 3 circular grids, $30 \mathrm{~cm}$ in diameter, each containing about 2000 circular holes for producing 2000 circular beamlets. The grids are shaped spherically concave to provide geometric focusing (aiming) with a focal length of $440 \mathrm{~cm}$ (the distance to the PDX torus port). Table 2 gives the $\mathrm{H}^{\circ}$ angular divergences for each neutral beam at the torus target horizontal focal plane (440 $\mathrm{cm})$. The results were obtained on the ORNL NB Test Stand from measurements of the respective beam power density profiles measured along the horizontal axis in the focal plane at the torus target using a scanning water calorimeter behind pin-hole apertures [1]. These power density profiles exhibit gaussian behavior down to about $10 \%$ of full power. Below the $10 \%$ power level, the profiles exhibit "wings" that have been characterized by asymmetric gaussian, or polynomial least-squares fitting.

TABLE 2. SUMMARY OF NBI OPTICS

\begin{tabular}{|l|l|l|}
\hline NBI & $\theta_{\text {ншнм }}$ & W ншнм $^{\circ}$ \\
\hline $\mathrm{S}$ & $1.5^{\circ}$ & $11.58 \mathrm{~cm}$ \\
\hline $\mathrm{E}$ & $1.13^{\circ}$ & $8.75 \mathrm{~cm}$ \\
\hline $\mathrm{NW}$ & $1.2^{\circ}$ & $9.25 \mathrm{~cm}$ \\
\hline $\mathrm{SW}$ & $0.94^{\circ}$ & $7.25 \mathrm{~cm}$ \\
\hline
\end{tabular}

Shown is the angular divergence $(\theta)$ from centerline to edge at one-half of maximum power (HWHM), and the beam half-width (W) from centerline to edge at one-half of maximum power (HWHM) at the focal plane.

NCSX NBI access requirements depend on the desired injected power, which in turn depends on the effective focal length, focusing, and steering of the output neutral beam. These factors are significant considerations in the design of long, tight, transition ducts for tangentially injecting beams. Preliminary NCSX neutral beam configurations and transition duct designs use the results shown in Table 2. The solid and dashed lines in Fig.1 show the simulated beam power density profile along the beam axis using the J. Whealton (ORNL) gaussian geometric optics code fit [3] to the measurements given in Table 2.

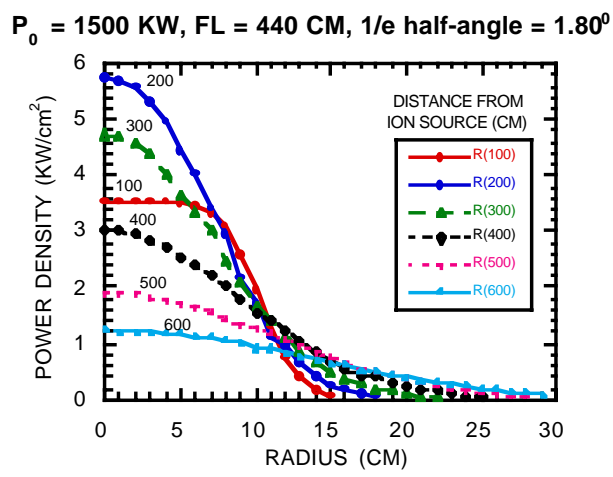

Fig. 1. Simulated power density along beam axis from 200 to 600 $\mathrm{cm}$ from the ion source. The beam port location will allow adequate duct width to avoid neutral and reionized power impingement on the duct walls.

\section{E. Control and Performance}

PDX developed full computerization for the NBI system, including control of filament, arc, and acceleration voltage conditioning, and fault response using an "artificial intelligence" algorithm incorporating "expert rules" [4,5]. One operator monitors all four systems in a "hands-off" manner. The computer control resulted in providing unforeseen benefits in operational reliability, reproducibility, and equipment safety.

\section{DESIGN OPTIMIZATION}

\section{A. Maximizing Injected Power}

The Neutral Beam power injected into NCSX can be maximized by reducing the system gas pressure in the transition duct which causes reionization and loss of neutral particles. A reduction of transition duct neutral gas pressure to the $\sim 10^{-5}$ torr regime can significantly increase the injected power incident on the plasma ( 12-18\%). The design plan for accomplishing this is discussed in Sec.D, below.

\section{B. Maximizing Desired Neutral Beam Species}

Typically, neutral beamlines are operated with the neutralizer cell at $\sim 90-95 \%$ equilibrium gas pressure to optimize the yield of the full energy component. The additional gas target through the transition duct can change the fractional ionic yield of the low energy components and produce small differences in the species ratios of injected beam. Small reductions in the percentage of the full energy component have been measured at the edges of beams in a narrow duct. High duct pressure may change the species ratios measured upstream in the beamline and broadens the beam power profile. These effects can be reduced by optimizing the duct design and installing 
additional cryopumping in the front box of the beamline.

\section{Power Transmission to the Far-Wall}

Neutral Beam power transmission to the farwall of the vessel ("shine-through") often requires at minimum, sufficient armor to absorb a short full power pulse. If sufficiently robust, this armor could allow short pulse power and position calibration injections in the absence of plasma. Simulations indicate that, for example, ATJ graphite at least 1.3 $\mathrm{cm}$ thick or the equivalent will be sufficient for wall armor tiles capable of absorbing the available peak NBI power densities of $3 \mathrm{~kW} / \mathrm{cm}^{2}$ for $500 \mathrm{msec}$ in the absence of plasma. Thicker tiles with active cooler will be needed as an upgrade for longer NBI pulse lengths. As the design evolves, if sufficient farwall armor cannot be installed at some locations (e.g., at RF antennas), then suitable interlocks capable of stopping beam injection will be applied, if sufficient plasma is not present.

\section{Minimizing Reionized Power Losss and Duct Wall Conditioning}

The reduction of duct outgassing by conditioning increases injected power and provides more reproducible results. Outgassing can be reduced by high conductance geometry, with walls far from the beam, appropriate materials, baking, and HeGDC between discharges. The NCSX design will include the installion of high-speed cryopumping in the exit box of the beamlines at the entrance to the duct to significantly reduce or eliminate the effects of duct outgassing. This hardware will also accelerate NCSX pumpdown between discharges.

Fig.2 is a schematic diagram which summarizes the NCSX NB duct and port access requirements discussed above. Shown are the principal elements of a high conductance NBI transition duct. The beam, after passing through the beamline Torus Interface Valve (TIV), enters a rectangular section which is usually connected to a cylindrical section attached to the vessel. In the case of PBX-M, reionized power loss due to residual process gas in the duct is steered to the duct side wall by the predominantly vertical fringe field at the entrance to the duct, and eventually to the top of the duct by the predominantly horizontal fringe field at the vessel entrance. A similar behavior is expected for NCSX and will be simulated as the design evolves. The duct has a ceramic break providing electrical isolation of about $3 \mathrm{kV}$, and a bellows at the vessel to decouple vessel motion during operation and bakeout. The bellows is shielded with a metal sheet

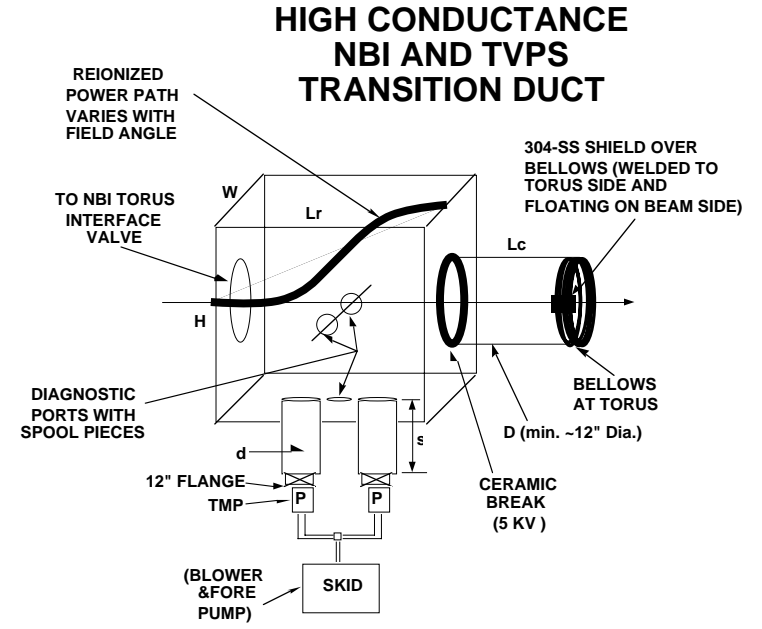

Fig.2. A partial schematic diagram showing the principal elements of a high conductance transition duct that combines the requirement of both NBI and TVPS requirements.

fastened to the vessel and floating on the beam side. Diagnostic ports are provided to provide viewing of the beam in the duct for NBI and plasma related measurements (e.g., Beam Emission Spectroscopy calibrations). Synergies accrue from combining duct requirements of the Neutral Beam and Torus Vacuum Pumping Systems by using the same ducts, and hence, it is desireable to maximize the width $\mathrm{W}$, the height $\mathrm{H}$, the diameter $\mathrm{D}$ and the diameter $\mathrm{d}$, while minimizing lengths $\mathrm{Lr}$ and Lc. Length $\mathrm{S}$ is selected for high conductance reaching a fringe field region comparable to that at the pumps during their PBX-M service. In addition, $\mathrm{S}$ is sufficiently long to provide occlusion from beam sputtering. Additional requirements to minimize duct outgassing are electropolished 304-SS walls, and $150^{\circ} \mathrm{C}$ bakeout capability. Some of these desired requirements are included in the preliminary conceptual design for a NCSX NB transition duct shown in Fig.3.
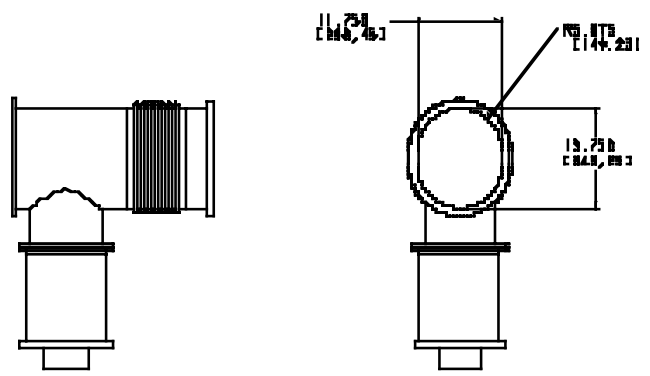

Fig.3. Candidate conceptual design for NCSX NB transition duct. 


\section{E. Maximzing Absorbed Power}

The NCSX design locates the NBI ports so as to maximize the absorption of injected beam power over the desired plasma region. The absorbed power is determined by the beam focusing (perveance), the distance of the ion source from the deposition region, the aiming angle, and target plasma parameters. Fig. 4 shows the proposed configuration. The vessel has 3 sectors; in each sector, the plasma cross-section changes from beanshaped to oblate and returns to bean-shaped.

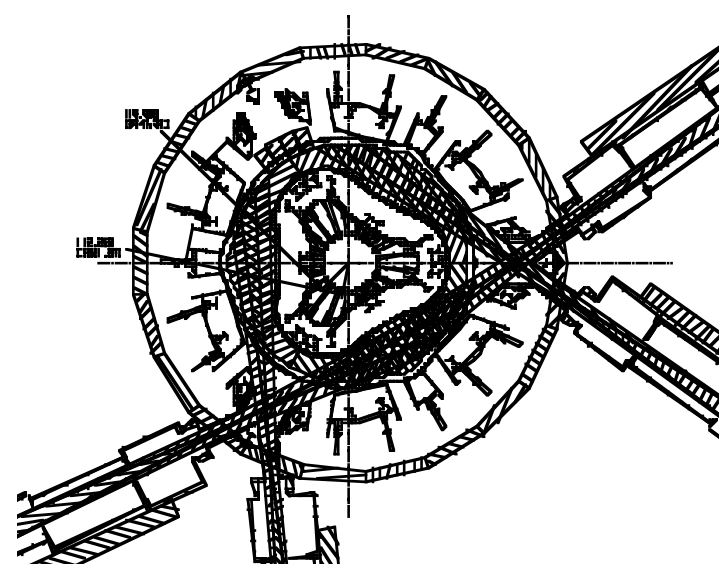

Fig.4 Proposed NCSX configuration for a 2 Co and 2 Counter NBI system.

Balanced co- and counter-tangential NB injection are needed to provide control of the neutral-beam driven currents, and to provide control of the driven rotation (and thus electric field) for transport studies. Fig. 4 shows a candidate configuration for $2 \mathrm{Co}$ and 2 Counter NBI systems positioned in the combined PBX-M and PLT Test Cells. The planed site layout will also accommodate beam configurations with three co- and one counter-injected beam.

A critcal element in this configuration is the transition duct region. Each transition duct region is partially shared by 2 beamlines, and nearby walls receive power from an oppositely directed NBI. The neutral beam is incident on a bean-shaped plasma cross-section which changes gradually to an oblate cross-section as residual beam reaches mid-sector. Fig.5 is a schematic diagram which shows the envelope of the oblate target plasma section. The large circle encloses $\sim 96 \%$ of the injected power from the most poorly focused NB (IS\#1, HWHM $=1.5^{\circ}$ ); the small circle encloses $\sim 47 \%$ of the injected power.

\section{F. Far-Wall Armor to Absorbs Beam Shine-thru \\ The NCSX design locates the NBI ports so} as to minimize beam power deposition on ports on

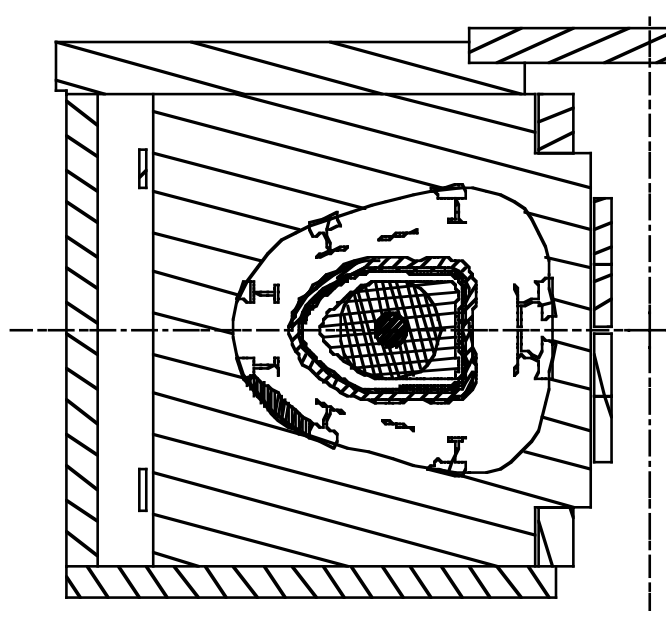

Fig.5. The envelope of the oblate target plasma section encloses more than $90 \%$ of the injected power.

the opposite wall. The design goal is to mount farwall armor to absorb shine-through so as to allow of plasma for calibrations while not oculting ports needed for RF Antennas and special diagnostic requirements.

\section{Conclusions}

The NCSX Neutral Beam design adopts the high performance NBI system of the PDX, PBX, and PBX-M projects which provided automated, reliable, economical operation. The design has the required heating power and pulse length. The design has power density profiles that can transit the available ports and heat the oblate target plasma. The design has co- and cntr- NBI for beam balance studies, and control of beam driven currents. The NCSX NBI design will provide an effective high power neutral beam system for the NCSX experimental program.

\section{REFERENCES}

[1] W. L. Gardner et al., "The ORNL Prototype PDX Neutral Beam Injection System", Proc. of the 8th Symp. on Engineering Problems of Fusion Research, (November 13-16, 1979) 972.

[2] H.W. Kugel et al., "Neutral Beam Species Measurements Using Insitu Rutherford Backscatter Spectrometry", Rev. Sci. Instrum. 56 (1985)1105.

[3] J. Kim and J. Whealton, "Beam Intensity Distributions in Neutral Beam Injection Systems", Nucl. Instrum. Methods. 141 (1977) 187.

[4] T. A. Kozub, et al., "A New Hardware and Software Configuration for the PBX-M Neutral beam Computer System" Proc. 12th Symp. on Fus. Eng. Res., ( Monterey, CA, October 1987) 606.

[5] K. Tuttle-Frank, et al., "A Rule-Based Computer Control System for PBX-M", Ibid. 596.

*This work is supported by U. S. DoE Contracts DE-AC02$76 \mathrm{CH} 030$ and DE-AC05-00OR22725. 


\section{External Distribution}

Plasma Research Laboratory, Australian National University, Australia

Professor I.R. J ones, Flinders University, Australia

Professor J oão Canalle, Instituto de Fisica DEQ/IF - UERJ , Brazil

Mr. Gerson O. Ludwig, Instituto Nacional de Pesquisas, Brazil

Dr. P.H. Sakanaka, Instituto Fisica, Brazil

The Librarian, Culham Laboratory, England

Library, R61, Rutherford Appleton Laboratory, England

Mrs. S.A. Hutchinson, JET Library, England

Professor M.N. Bussac, Ecole Polytechnique, France

Librarian, Max-Planck-Institut für Plasmaphysik, Germany

J olan Moldvai, Reports Library, MTA KFKI-ATKI, Hungary

Dr. P. Kaw, Institute for Plasma Research, India

Ms. P.J . Pathak, Librarian, Insitute for Plasma Research, India

Ms. Clelia De Palo, Associazione EURATOM-ENEA, I taly

Dr. G. Grosso, Instituto di Fisica del Plasma, Italy

Librarian, Naka Fusion Research Establishment, J AERI, J apan

Library, Plasma Physics Laboratory, Kyoto University, J apan

Research Information Center, National Institute for Fusion Science, J apan

Dr. O. Mitarai, Kyushu Tokai University, J apan

Library, Academia Sinica, Institute of Plasma Physics, People's Republic of China

Shih-Tung Tsai, Institute of Physics, Chinese Academy of Sciences, People's Republic of China

Dr. S. Mirnov, TRINITI, Troitsk, Russian Federation, Russia

Dr. V.S. Strelkov, Kurchatov Institute, Russian Federation, Russia

Professor Peter Lukac, Katedra Fyziky Plazmy MFF UK, Mlynska dolina F-2, Komenskeho Univerzita, SK-842 15 Bratislava, Slovakia

Dr. G.S. Lee, Korea Basic Science Institute, South Korea

Mr. Dennis Bruggink, Fusion Library, University of Wisconsin, USA

Institute for Plasma Research, University of Maryland, USA

Librarian, Fusion Energy Division, Oak Ridge National Laboratory, USA

Librarian, Institute of Fusion Studies, University of Texas, USA

Librarian, Magnetic Fusion Program, Lawrence Livermore National Laboratory, USA

Library, General Atomics, USA

Plasma Physics Group, Fusion Energy Research Program, University of California at San Diego, USA

Plasma Physics Library, Columbia University, USA

Alkesh Punjabi, Center for Fusion Research and Training, Hampton University, USA

Dr. W.M. Stacey, Fusion Research Center, Georgia Institute of Technology, USA

Dr. J ohn Willis, U.S. Department of Energy, Office of Fusion Energy Sciences, USA

Mr. Paul H. Wright, Indianapolis, Indiana, USA 
The Princeton Plasma Physics Laboratory is operated by Princeton University under contract with the U.S. Department of Energy.

\author{
Information Services \\ Princeton Plasma Physics Laboratory \\ P.O. Box 451 \\ Princeton, NJ 08543
}

Phone: 609-243-2750

Fax: 609-243-2751

e-mail: pppl_info@pppl.gov

Internet Address: http://www.pppl.gov 